\title{
Mosquitocidal properties of Bacillus species isolated from mangroves of Vellar estuary, Southeast coast of India
}

\author{
S. Balakrishnan $\cdot$ K. Indira $\cdot$ M. Srinivasan
}

Received: 7 June 2013/Accepted: 18 October 2013/Published online: 1 November 2013 (c) Indian Society for Parasitology 2013

\begin{abstract}
Samples collected from the mangroves of Vellar estuary yielded a mosquitocidal bacterium, whose secondary metabolites exhibited mosquito larvicidal and pupicidal activity. The bacterium was isolated using standard microbiological methods and identified using classical biochemical tests. The mosquitocidal bacterium was identified as Bacillus subtilis, Bacillus thuringiensis, Bacill 's sphaericus and Bacillus cereus. Mosquitocidal metabo lite(s) was separated from the culture supernatan of the bacterium and its efficacy was against the larval a $r_{\text {upal }}$ stages of two different species of mosquito $s$ and $c$. mined in terms of $\mathrm{LC}_{50}$ and $\mathrm{LC}_{90}$. Mo qu larvicidal activity in terms of $\mathrm{LC}_{50}$ against Anophrys step $\psi$ si and Aedes aegypti was 4.374 and $7.406 \mathrm{r} / \mathrm{ml}$ and its pupicidal activity was 4.928 and $9.865 \mu \mathrm{l} / \mathrm{r}$ respectively. The present study proved that the mosqui. properties of the Bacillus species isolated mangroves of Vellar estuary was evaluated as target species of mosquito vectors. This is an ideal eco- endly approach for the vector control programs.

Keywords $B a c_{\text {a }}$ species - Culture supernatant . Mosquito p picidal 'ángroves · Vellar estuary

S. b Trishnan $(\varangle) \cdot$ K. Indira $\cdot$ M. Srinivasan

Centre Advanced Study in Marine Biology, Faculty of Marine

Sciences, Annamalai University, Parangipettai 608 502, Tamil

Nadu, INDIA

e-mail: marugalbalu82@gmail.com

K. Indira

e-mail: microind03@yahoo.co.in

M. Srinivasan

e-mail: mahashrini1@gmail.com
\end{abstract}

\section{保}


mosquitoes as well as the pathogens they transmit, there has been resurgence in the incidence of mosquito borne disease. Although chemical insecticides provide effective control of mosquitoes, development of resistance to them has been widely reported (WHO 1992; Rodriguez et al. 2001). There are 350-500 million clinical cases of malaria per year with about one million deaths. In India, around two million malaria cases are being reported annually (Kumar et al. 2007). Around the world, the medical and economic burden caused by vector-borne disease continues to grow as current control measures fail to cope. There is an urgent need to identify new control strategies that will remain effective, even in the face of growing insecticide and drug resistance (Achs and Malaney 2002). Vector control strategies include chemical based control measures, non-chemical based control measures and biological control agents (Poopathi and Tyagi 2006). Repetitive use of man-made insecticides for mosquito control disrupts natural biological control systems and lead to reappearance of mosquito populations. It also resulted in the development of resistance, detrimental effects on non-target organisms and human health problems and subsequently this initiated a search for alternative control measures (Das et al. 2007; Zhang et al. 2011).

An alternative is the microbial pesticides and is advantageous as they are eco-friendly and specific to the tar organisms. Among various microbial pesticides, Bacillu thuringiensis and $B$. sphaericus are being used widely as larvicidal bacteria for mosquito control (Balaram. 1, 35 ; Lee and Zairi 2005; Medeiros et al. 2005; A mengol $\%$. 2006). However, the development of resist nc B. sphaericus by vector mosquitoes (Nielsen-I toux et 1995 ; Poopathi et al. 1999; Su and Mulla 204), prompred us to search for new mosquitocidal bacteri There are reports of isolation of Clostridum bifermentans, naerobic spore former and B. thuringiensis sub $\mathrm{s}_{1}$ olensis/tochigiensis an aerobic spore former, from mangroye ss vamps and mangrove sediments of Malaysia an Japan (de Barjac et al. 1990; Maeda et al. 2001) hous biocontrol agent, $B$. thuringiensis sub o. israea is and B. sphaericus have been extensively stu ita. nd used for mosquito control (Medeiros et al. 2005; rmengo d. 2006). Few other bacterial strains such as $P$ alvei and B. brevis (Khyami-Horani et al. 1999), Brevibact taier sporus (Shida et al. 1996), B. circulans (D.1. and agard 2002) and B. subtilis (Das and Mukt. ee also have been reported to act against mosquito. Usiı. ntomopathogenic bacteria to control mosquitoes is a promis,, $\mathrm{g}$ environmentally friendly alternative to chemical insecticides (Park and Federici 2009). The most widely used alternative control agents for mosquitoes are the insecticidal spore B. sphaericus (Federici et al. 2006; Park et al. 2010). These bacteria produce parasporal endotoxin crystals during sporulation and these crystal proteins are responsible for their mosquitocidal activity. However, mosquito colonies develop resistance to B. sphaericus over a period of time where it is used extensively (Rao et al. 1995; Silva-Filha et al. 1995; Yuan et al. 2000). Although no resistance to B. thuringiensis sub sp. israelensis has been reported in the field yet, laboratory selection of mosquitoes with $B$. thuringiensis sub sp israelensis proteins results in high levels of resistance (Georghiou and Wirth 1997; Wirth et al. 1997). Furthermore, mosquito resistance to any of these prote $r$ ylts in significant cross-resistance to the others (Wirth a1. 2007). Mosquitoes, causing filariasis, mala and encelnalitis, are also known to occur in mangrove fo ts. B at there is no devoted study on mosquitoes of particu. coastal area of India covering mangroves, est ry and backwaters. Incidence of mosquito-borne diseas in no pettai, located near the Vellar estuary, signal that riasis high in this area. These bacterium were id ified anc characterized through morphological and biuche. 91 methods and their mosquitocidal activity was a ed agat,st larval and pupal stages of vector species fro ma maros.

Materi Ils a., methods

Sample collection

B. cterial strains were isolated from Parangipettai mangrove cosystem, southeast coast of India. $10 \mathrm{~g}$ of soil samples was collected using sterile spatula and stored in sterile screw capped vials. Water samples of $10 \mathrm{ml}$ were collected from marshy swamps and pits using sterile Pasteur pipette. To get samples with minimal effect of ultraviolet (UV) light, soil and water samples were collected from about $2-3 \mathrm{~cm}$ below the surface of the habitat. Leaf samples were collected using sterile scalpel from mangroves. To get the maximum UV protected phylloplane microbial population, they were obtained from 2.0 to $2.5 \mathrm{~m}$ above the ground and $0.3 \mathrm{~m}$ inside the outer leaf canopy of each tree or shrub.

\section{Isolation of bacteria}

After collection, samples were brought to the laboratory. $1 \mathrm{~g}$ of soil was weighed, transferred to a vial containing $10 \mathrm{ml}$ of sterile water, and kept on a rotary shaker (New Brunswick Scientific Co. Inc., NJ, USA) at $100 \mathrm{rpm}$ for $30 \mathrm{~min}$, to dislodge bacterial cells from the soil particles. The supernatant was diluted tenfold and $0.1 \mathrm{ml}$ was spread on pre-solidified nutrient yeast salt mineral agar (NYSM) containing $5 \mathrm{~g}$ glucose (bacteriological), $5 \mathrm{~g}$ peptone, $5 \mathrm{~g} \mathrm{NaCl}, 3 \mathrm{~g}$ beef extract, $5 \mathrm{~g}$ yeast extract, $203 \mathrm{mg} \mathrm{MgCl}$, $10 \mathrm{mg} \mathrm{MnCl} 2$ and $103 \mathrm{mg} \mathrm{CaCl}_{2}$ (HiMedia, India) per liter of distilled water. Similarly, water samples were diluted tenfold with sterile water and plated as above. Leaf samples were transferred to $10 \mathrm{ml}$ sterile 
water, kept on a rotary shaker for 30 min, diluted tenfold and plated as above. The bacterial suspensions were not subjected to pasteurisation before plating, expecting both gram-positive and gram-negative bacteria with mosquitocidal activity. The plates were incubated at $30{ }^{\circ} \mathrm{C}$ for $48 \mathrm{~h}$ and bacterial colonies which formed were purified on NYSM agar. Each of the purified colonies was then sub cultured on NYSM agar slants, allowed to grow for $72 \mathrm{~h}$ and stored at $4{ }^{\circ} \mathrm{C}$. These bacterial isolates were screened for mosquito larvicidal activity (Sneath 1986).

Mosquito culture

The eggs of A. aegypti/A. stephensi were collected in and around Parangipettai area with the help of ' $O$ ' type brush.
$8,000 \mathrm{rpm}$ for $20 \mathrm{~min}$ and bioassayed independently, as mentioned above. The dose of CS used was $1 \mathrm{ml}$ while that of cell mass was $1 \mathrm{mg}$ per $100 \mathrm{ml}$ of water.

\section{Larval/pupal toxicity test}

Laboratory colonies of mosquito larvae/pupae were used for the larvicidal/pupicidal activity. Twe fo $n$ mbers of third instar and pupae (A. stephensi/A. . vp $\iota$ ) were introduced into wax coated paper pos contain $125 \mathrm{ml}$ of dechlorinated tap water an 1 of an-inoculated NYSM broth. At each teste concentr, on, one to five different concentrations wer made for each Bacillus species. The control mor 'itie ar corrected by using Abbott's (1925) form la.

$$
\text { Corrected mortality }=\frac{\text { Observed mortality in treatment }- \text { Observed mo\% }}{100-\text { Control morality }} \text { Percentage mortality }=\frac{\text { Number of dead larvae/pupae }}{\text { Number of larvae/pupae introduced }} \times 100
$$

The eggs were transferred to $18 \times 13 \times 4 \mathrm{~cm}$-size enam trays containing $500 \mathrm{ml}$ of water for larval hatchin larvae were fed a diet of brewer's yeast, dog biscuits. quito larval and pupal culture was maintain $\mathrm{d}$ in the $\mathrm{b}$ oratory. Pupae were transferred to plastic Ja containing tap water which was placed in wood $n$ mosc $y$ cage $(90 \times 90 \times 90 \mathrm{~cm})$ where adults em rged .

Screening for mosquito larvicidal and

A loopful of bacteria from the NY\%M slant was inoculated to $10 \mathrm{ml}$ of NYSM bro 1 incu a $\left(30^{\circ} \mathrm{C}\right)$ on a rotary shaker (200 rpm) for or incubation, sample of $1 \mathrm{ml}$ each from the who, ulture was used to screen for mosquito larviclu and pupicidal activity through bioassay. Bioass vs were nducted in wax coated paper cups containin 25 third instar larvae/pupae of A. aegypti/A. stephenst 100 al chlorine-free tap water. Appropriate con with the addition of the bacterial culture, but 5 tair $1 / \mathrm{ml}$ of un-inoculated NYSM broth, were man ined. After $24 \mathrm{~h}$ of exposure, mortality was scored by coulang the number of alive larvae/pupae present in the respective cups. A bacterial isolate was considered potent if it caused $100 \%$ mortality of the test larvae or pupae. The potential bacterial cultures were further screened to find out whether the bacterial cells or their metabolites exhibited mosquitocidal activity. The cells and culture supernatant (CS) were separated by centrifuging the active cultures at
The $\mathrm{LC}_{50}$ and $\mathrm{LC}_{90}$ were calculated from toxicity data sing probit analysis (Finney 1971).

Statistical analysis

The average larval mortality data were subjected to probit analysis for calculating $\mathrm{LC}_{50}$ and $\mathrm{LC}_{90}$, and other statistics at $95 \%$ confidence limit (LCL) and $\chi^{2}$ values were calculated using the SPSS 16.0 version (Statistical software package) to find the regression equation values. Results with $P \leq 0.05$ were considered to be statistically significant.

\section{Results}

The bacteria were isolated from 3 soil, 5 leaf and 4 water samples of mangrove habitat. A total of 15 bacteria were selected randomly from the isolates and screened for mosquitocidal activity. Preliminary screening with $1 \mathrm{ml}$ of culture supernatant and/or $1 \mathrm{mg}$ of SCC showed that 10 bacterial strains had mosquito larvicidal and pupicidal properties. Subsequently, all the 10 strains were bioassayed at different concentrations to find out their dosage dependent effect and upon this, three strains showed activity even at low concentrations. In screening assay ten bacterial cultures were used for larvicidal activity of A. stephensi and $A$. aegypti mosquito among which the ten of the isolates have been effective. 


\section{Mosquitocidal potential of the bacterial strains}

The culture supernatants of $B$. subtilis, B. thuringiensis, $B$. sphaericus and $B$. cereus were taken and each was arranged as five different concentrations $(1,2,3,4$ and $5 \mu \mathrm{l} / \mathrm{ml})$ to find out the more toxic to the third instar larvae and pupae of A. stephensi and A. aegypti. Culture supernatant of $B$. thuringiensis $(5 \mu \mathrm{l} / \mathrm{ml})$ was more toxic to the pupae of $A$. stephensi. Similarly $4 \mu \mathrm{l} / \mathrm{ml}$ concentration of $B$. thuringiensis was toxic to the pupae of $A$. aegypti, compared to that of $B$. subtilis. The larvae and pupae of $A$. aegypti were more susceptible to $1 \mu \mathrm{l} / \mathrm{ml}$ of culture supernatant of $B$. thuringiensis. Against A. Aegypti, the larvicidal and pupicidal activity was higher in $5 \mu \mathrm{l} / \mathrm{ml}$ of $B$. subtilis. The percentage mortality of third instar larvae and pupae of $A$. stephensi and $A$. aegypti mosquito by $B$. subtilis, $B$. thuringiensis, B. sphaericus and B. cereus were represented in the Tables 1, 2, 3 and 4. Although the isolated microbes were effective in control of A. stephensi and A. aegypti while $B$. thuringiensis was found to be highly effective which exhibit $92 \pm 1 \%$ mortality. The percentage mortality was varied with concentration of isolated microbial suspension and the incubation time.

Mosquito larvicidal activity of $B$. subtilis in terms of $\mathrm{LC}_{50}$ and $\mathrm{LC}_{90}$ values against $A$. stephensi were $3.803 \mathrm{a}$ $6.129 \mu \mathrm{l} / \mathrm{ml}$ while against $A$. aegypti was 3.742 an $6.079 \mu \mathrm{l} / \mathrm{ml}$. Mosquito pupicidal activity of $B$. subtilis in terms of $\mathrm{LC}_{50}$ and $\mathrm{LC}_{90}$ values against $A$. stepm i was 3.156 and $5.234 \mu \mathrm{l} / \mathrm{ml}$ while against $A$. aegyp it was . 65 and $5.433 \mu \mathrm{l} / \mathrm{ml}$. The regression equa 10 values of B. subtilis for third instar larvae/pun of $A$. phensi were $Y=-2.094+0.550 X \quad$ a id $\quad Y=-1.946+$ $0.616 X$ while for A. aegypti $Y=-051+0.548 X$ and $Y=-1.930+0.591 X$, respectively. ong the third instar larvae were more suscept han the pupae. The $B$. subtilis showed considerable larvicidal and pupicidal activity. The $\chi^{2}$ values were more significant $(P \leq 0.05)$ for A. aegypti than A. stephensi (Table 1).

Mosquito larvicidal activity in $B$. thuringiensis in terms of $\mathrm{LC}_{50}$ and $\mathrm{LC}_{90}$ values against $A$. stephensi was 3.488 and $6.573 \mu \mathrm{l} / \mathrm{ml}$ while against $A$. aegypti it was 2.356 and $5.278 \mu \mathrm{l} / \mathrm{ml}$. Mosquito pupicidal activity in B. thuringiensis in terms of $\mathrm{LC}_{50}$ and $\mathrm{LC}_{90}$ values ag st phensi was 3.129 and $4.968 \mu \mathrm{l} / \mathrm{ml}$ while against $A$. $\quad v p a$ it was 2.685 and $4.639 \mu \mathrm{l} / \mathrm{ml}$. The regres on equation values of B. thuringiensis for third instar lervac pa o. A. stephensi were $Y=-1.449+0.415 X$ and $Y=-180+0.696 X$ while against $A$. aegypti it wa $Y=-1.003+0.439 X$ and $Y=-1.760+0.656 X$ esp were more susceptibl than pupae. The B. thuringiensis showed considerab larvicida and pupicidal activity. The $\chi^{2}$ values were signith $(P \leq 0.05)$ at $A$. aegypti than $A$. stephensi ( $\mathrm{T}$ ? $)$.

Mosqui ary activity in B. sphaericus in terms of $\mathrm{LC}_{50}$ and $\mathrm{LC}$, values against $A$. stephensi was 3.915 and $6.851 \mathrm{~N} / \mathrm{ml}$ whle against A. Aegypti it was 3.252 and $6.397 \mu \mathrm{l} / \mathrm{n} /$. . osquito pupicidal activity in B. sphaericus in terms of $\mathrm{LC}_{50}$ and $\mathrm{LC}_{90}$ values against $A$. stephensi was 3.267 and $6.615 \mu \mathrm{l} / \mathrm{ml}$ while against $A$. aegypti it was 4.256 $6.619 \mu \mathrm{l} / \mathrm{ml}$. The regression equation values of B. sphaericus for third instar larvae/pupa of A. stephensi vere $Y=-1.709+0.437 X$ and $Y=-1.250+$ $0.383 X$ while of A. aegypti $Y=-1.325+0.407 X$ and $Y=-2.307+0.542 X$, respectively. The third instar larvae were more susceptible than the pupae. The $B$. sphaericus showed considerable larvicidal and pupicidal activity. The $\chi^{2}$ values were significant $(P \leq 0.05)$ for $A$. aegypti than A. stephensi (Table 3).

Mosquito larvicidal activity in B. cereus in terms of $\mathrm{LC}_{50}$ and $\mathrm{LC}_{90}$ values against $A$. stephensi was 3.488 and

Table 1 Bioassay results $C^{-}$Ire sul ernatant of B. subtilis against third instar larvae and pupae of two species of mosquitoes

\begin{tabular}{|c|c|c|c|c|c|c|c|c|c|}
\hline \multirow[t]{2}{*}{$\begin{array}{l}\text { Mosquito } \\
\text { species }\end{array}$} & \multirow{2}{*}{ Pupa $\left(\mu 1 / \mathrm{m}_{\mathrm{i}}\right.$} & $\mathrm{CL}$ & \multirow[t]{2}{*}{ Regression equation } & \multirow[t]{2}{*}{$\chi^{2}$} & \multicolumn{2}{|c|}{$\begin{array}{l}\text { Larva } \\
(\mu \mathrm{l} / \mathrm{ml})\end{array}$} & \multirow[t]{2}{*}{$\begin{array}{l}95 \% \text { FL } \\
\text { (LCL-UCL) }\end{array}$} & \multirow[t]{2}{*}{ Regression equation } & \multirow[t]{2}{*}{$\chi^{2}$} \\
\hline & & & & & $\mathrm{LC}_{50}$ & $\mathrm{LC}_{90}$ & & & \\
\hline & 5.2 & $2.736-3.594$ & $Y=-1.946+0.616 X$ & $2.273 *$ & 3.803 & 6.129 & $3.349-4.395$ & $Y=-2.094+0.550 X$ & $0.872 *$ \\
\hline A. & 5.433 & $5.242-7.551$ & $Y=-1.930+0.591 X$ & $1.059 *$ & 3.742 & 6.079 & $5.749-8.734$ & $Y=-2.051+0.548 X$ & $3.918 *$ \\
\hline \multirow[t]{2}{*}{$\begin{array}{l}\text { Mosquit } \\
\text { species }\end{array}$} & Pupa $(\mu \mathrm{l} / \mathrm{ml})$ & \multirow[t]{2}{*}{$\begin{array}{l}95 \% \text { FL } \\
\text { (LCL-UCL) }\end{array}$} & \multirow[t]{2}{*}{ Regression equation } & \multirow[t]{2}{*}{$\chi^{2}$} & \multicolumn{2}{|c|}{$\begin{array}{l}\text { Larva } \\
(\mu 1 / \mathrm{ml})\end{array}$} & \multirow[t]{2}{*}{$\begin{array}{l}95 \% \text { FL } \\
\text { (LCL-UCL) }\end{array}$} & \multirow[t]{2}{*}{ Regression equation } & \multirow[t]{2}{*}{$\chi^{2}$} \\
\hline & $\mathrm{LC}_{90}$ & & & & $\mathrm{LC}_{50}$ & $\mathrm{LC}_{90}$ & & & \\
\hline A. stephensi & 3.1294 .968 & $4.836-6.621$ & $Y=-2.180+0.696 X$ & $3.869 *$ & 3.488 & 6.573 & $6.080-10.678$ & $Y=-1.449+0.415 X$ & $0.619 *$ \\
\hline A. aegypti & $2.685 \quad 4.639$ & $4.004-10.597$ & $Y=-1.760+0.656 X$ & $5.451 *$ & 2.356 & 5.278 & $5.047-8.477$ & $Y=-1.003+0.439 X$ & $1.108 *$ \\
\hline
\end{tabular}

$* P \leq 0.05$ level 
Table 3 Bioassay results of culture supernatant of B. sphaericus against third instar larvae and pupae of two species of mosquitoes

\begin{tabular}{|c|c|c|c|c|c|c|c|c|c|c|}
\hline \multirow[t]{2}{*}{$\begin{array}{l}\text { Mosquito } \\
\text { species }\end{array}$} & \multicolumn{2}{|c|}{ Pupa $(\mu \mathrm{l} / \mathrm{ml})$} & \multirow[t]{2}{*}{$\begin{array}{l}95 \% \text { FL } \\
\text { (LCL-UCL) }\end{array}$} & \multirow[t]{2}{*}{ Regression equation } & \multirow[t]{2}{*}{$\chi^{2}$} & \multicolumn{2}{|c|}{$\begin{array}{l}\text { Larva } \\
(\mu \mathrm{l} / \mathrm{ml})\end{array}$} & \multirow[t]{2}{*}{$\begin{array}{l}95 \% \text { FL } \\
\text { (LCL-UCL) }\end{array}$} & \multirow[t]{2}{*}{ Regression equation } & \multirow[t]{2}{*}{$\chi^{2}$} \\
\hline & $\mathrm{LC}_{50}$ & $\mathrm{LC}_{90}$ & & & & $\mathrm{LC}_{50}$ & $\mathrm{LC}_{90}$ & & & \\
\hline A. stephensi & 3.267 & 6.615 & $6.079-11.306$ & $Y=-1.250+0.383 X$ & $1.296^{*}$ & 3.915 & 6.851 & $6.299-10.898$ & $Y=-1.709+0.437 X$ & $0.448^{*}$ \\
\hline A. aegypti & 4.256 & 6.619 & $5.279-39.288$ & $Y=-2.307+0.542 X$ & $6.500 *$ & 3.252 & 6.397 & $5.935-10.498$ & $Y=-1.325+0.407 X$ & $0.692 *$ \\
\hline
\end{tabular}

Table 4 Bioassay results of culture supernatant of B. cereus against third instar larvae and pupae of two speci of

\begin{tabular}{|c|c|c|c|c|c|c|c|c|c|}
\hline \multirow[t]{2}{*}{$\begin{array}{l}\text { Mosquito } \\
\text { species }\end{array}$} & \multicolumn{2}{|c|}{ Pupa $(\mu 1 / m l)$} & \multirow[t]{2}{*}{$\begin{array}{l}95 \% \text { FL } \\
\text { (LCL-UCL) }\end{array}$} & \multirow[t]{2}{*}{ Regression equation } & \multirow[t]{2}{*}{$\chi^{2}$} & \multicolumn{2}{|c|}{$\begin{array}{l}\text { Larva } \\
(\mu \mathrm{l} / \mathrm{ml})\end{array}$} & \multirow[t]{2}{*}{$\begin{array}{l}95 \% \text { FL } \\
(\mathrm{LCL}-\mathrm{UCL} \text { ) }\end{array}$} & \multirow[t]{2}{*}{$\chi^{2}$} \\
\hline & $\mathrm{LC}_{50}$ & $\mathrm{LC}_{90}$ & & & & $\mathrm{LC}_{50}$ & $\mathrm{LC}_{90}$ & & \\
\hline A. stephensi & 4.928 & 9.865 & $7.982-26.926$ & $Y=-1.279+0.259 X$ & $0.650 *$ & 3.488 & 6.573 & $679 \quad Y=-1.449+0.415 X$ & $0.619 *$ \\
\hline A. aegypti & 4.848 & 7.946 & $7.029-13.626$ & $Y=-2.005+0.414 X$ & $1.658 *$ & 4.374 & 7.406 & $Y=-1.848+0.423 X$ & $1.148 *$ \\
\hline
\end{tabular}

Table 5 Screening the biological effects of B. subtilis secondary metabolites again tw: species of mosquitoes

\begin{tabular}{|c|c|c|c|c|c|c|c|c|}
\hline \multirow[t]{3}{*}{ Mosquito species } & \multicolumn{3}{|c|}{ B. subtilis against third instar larvae $(\mu \mathrm{l} / \mathrm{ml})$} & \multicolumn{5}{|c|}{ B. subtilis against pupae $(\mu \mathrm{l} / \mathrm{ml})$} \\
\hline & \multicolumn{3}{|c|}{ Concentration $(\%)$} & \multicolumn{5}{|c|}{ Concentration $(\%)$} \\
\hline & 1 & 2 & 3 & 1 & 2 & 3 & 4 & 5 \\
\hline A. stephensi & $12 \pm 1$ & $20 \pm 1$ & $84 \pm 1$ & $8 \pm 1$ & $13 \pm 2$ & $33 \pm 2$ & $60 \pm 2$ & $73 \pm 2$ \\
\hline A. aegypti & $9 \pm 1$ & $21 \pm 1$ & $80 \pm 2$ & $7 \pm 1$ & $16 \pm 2$ & $41 \pm 2$ & $42 \pm 2$ & $84 \pm 2$ \\
\hline
\end{tabular}

Table 6 Screening the biological effects of B. thuringiensis secondary metabolites against two species of mosquitoes

\begin{tabular}{|c|c|c|c|c|c|c|c|c|c|}
\hline \multirow[t]{3}{*}{ Mosquito species } & \multirow{2}{*}{$\begin{array}{l}\text { B. thuringiensis agail } \\
\text { Concentration }\end{array}$} & \multicolumn{3}{|c|}{ hird in tar larvae $(\mu \mathrm{l} / \mathrm{ml})$} & \multicolumn{5}{|c|}{ B. thuringiensis against pupae $(\mu 1 / \mathrm{ml})$} \\
\hline & & & & & \multicolumn{5}{|c|}{ Concentration $(\%)$} \\
\hline & 1 & 3 & 4 & 5 & 1 & 2 & 3 & 4 & 5 \\
\hline A. stephensi & & $32 \pm 2$ & $80 \pm 2$ & $5 \pm 1$ & $13 \pm 2$ & $33 \pm 2$ & $42 \pm 2$ & $60 \pm 3$ & $73 \pm 2$ \\
\hline A. aegypti & & $41 \pm 1$ & $88 \pm 2$ & $12 \pm 2$ & $32 \pm 3$ & $40 \pm 2$ & $60 \pm 2$ & $72 \pm 2$ & $92 \pm 1$ \\
\hline
\end{tabular}

$6.573 \mu \mathrm{l} / \mathrm{m}$. while as ast $A$. aegypti it was 4.374 and $7.406 \mu^{1}$ 1. Mosquito pupicidal activity in B. cereus in terms of $\mathrm{L}$ an $\mathrm{LC}_{90}$ values against $A$. stephensi was $4 .{ }^{2} 28$ an $9.0,5 \mu \mathrm{l} / \mathrm{ml}$ and for $A$. aegypti it was 4.848 a. $7 / \mathrm{ml}$. The regression equation values of $B$. $c_{\text {u }}$ for third instar larvae/pupa of A. stephensi $Y=-1.449+0.415 X$ and $Y=-1.279+0.259 X$ while for A. aegypti $Y=-1.848+0.423 X$ and $Y=-2.005+$ $0.414 X$. The third instar larvae were more susceptible than the pupae. The B. cereus showed considerable larvicidal and pupicidal activity. The Chi square values were significant $(P \leq 0.05)$ for $A$. aegypti than A. stephensi (Table 4).
The initial concentration $(1 \mu \mathrm{l} / \mathrm{ml})$ of four microbial strains showed the mortality about $100 \%$, further the mortality rate was found to be higher with the increased concentration and was significant to each other and their mortality range was about $50-75 \%$ within $24 \mathrm{~h}$. The mortality rate was gradually increased with the incubation time range between 4 and $92 \%$ in $48 \mathrm{~h}$ which is represented in the Tables 2, 3 and 4. The three microbial isolates B. thuringiensis, B. cereus and B. subtilis were effective which cause $92 \%$ larval and pupa mortality at $48 \mathrm{~h}$ incubation in the bacterial concentrations of $2.356 \pm 7.406 \mu \mathrm{l} / \mathrm{ml}$ and $2.685 \pm 9.865 \mu \mathrm{l} / \mathrm{ml}$ (Tables 5, 6, 7, 8). 
Table 7 Screening the biological effects of B. sphaericus secondary metabolites against two species of mosquitoes

\begin{tabular}{|c|c|c|c|c|c|c|c|c|c|c|}
\hline \multirow[t]{3}{*}{ Mosquito species } & \multicolumn{5}{|c|}{ B. sphaericus against third instar larvae $(\mu 1 / \mathrm{ml})$} & \multicolumn{5}{|c|}{ B. sphaericus against pupae $(\mu 1 / \mathrm{ml})$} \\
\hline & \multicolumn{5}{|c|}{ Concentration $(\%)$} & \multicolumn{5}{|c|}{ Concentration $(\%)$} \\
\hline & 1 & 2 & 3 & 4 & 5 & 1 & 2 & 3 & 4 & 5 \\
\hline A. stephensi & $21 \pm 1$ & $20 \pm 2$ & $32 \pm 2$ & $32 \pm 2$ & $40 \pm 2$ & $13 \pm 2$ & $13 \pm 2$ & $22 \pm 3$ & $30 \div 2$ & $47 \pm 2$ \\
\hline A. aegypti & $8 \pm 1$ & $12 \pm 2$ & $20 \pm 2$ & $28 \pm 2$ & $81 \pm 1$ & $13 \pm 2$ & $20 \pm 2$ & $33 \pm 2$ & & \\
\hline
\end{tabular}

Table 8 Screening the biological effects of B. cereus secondary metabolites against two species of mosquitoes

\begin{tabular}{|c|c|c|c|c|c|c|c|c|}
\hline \multirow[t]{3}{*}{ Mosquito species } & \multicolumn{5}{|c|}{ B. cereus against third instar larvae $(\mu \mathrm{l} / \mathrm{ml})$} & \multicolumn{3}{|c|}{ B. cereus against pupae $(\mu \mathrm{Ml} / \mathrm{ml})$} \\
\hline & \multicolumn{5}{|c|}{ Concentration (\%) } & \multicolumn{3}{|l|}{ Concentration $(\%)$} \\
\hline & 1 & 2 & 3 & 4 & 5 & 1 & 4 & 5 \\
\hline A. stephensi & $12 \pm 1$ & $24 \pm 2$ & $36 \pm 1$ & $39 \pm 1$ & $48 \pm 2$ & $13 \pm 1$ & $40 \pm 2$ & $49 \pm 2$ \\
\hline A. aegypti & $9 \pm 1$ & $12 \pm 2$ & $20 \pm 2$ & $28 \pm 2$ & $60 \pm 2$ & $4 \pm 2$ & $40 \pm 2$ & $60 \pm 2$ \\
\hline
\end{tabular}

\section{Discussion}

Natural sample is an excellent residence for plentiful microbes as they have ability to produce secondary metabolites applied in industrial production processes and biocontrol activities. Basis of this, natural as well harmless microbial isolates screened and isolated from th. mangrove environment for mosquito larvicidal properties under laboratory condition. Previous studies prov th $B$. thuringiensis subsp. israelensis (Bti) and P. spha vu (Bsp) were entomopathogenic bacteria that ability to control the larvae of A. aegypti mosinutoes as and Amalraj 1997). Present study, revie ed that the B. thuringiensis, B. sphaericus, B. cereus an B. subtilis also have the ability to control Anopheleus step a nd A. aegypti larvae effectively. The mosq idal strain $B$. subtilis showed vegetative growth from $4 \mathrm{t} / 5 \mathrm{~h}$ and then initiated sporulation. The prodyen of ingsquitocidal toxin was initiated after the las ha. , at fourth hour and the maximum mosquitoeida ctivity was obtained at $12 \mathrm{~h}$. Hence, the mo q. cidal toxins in B. subtilis are produced during the yegetativ hase of growth unlike in the case of B. thurin iensis and B. sphaericus where mosquitocidal toxin pro an an sompanied sporulation (Aronson et al. 198 3. $s p$ cus is a spore forming aerobic bacterium, 5 eral trains of which are pathogenic for mosquito larvae. In t. present study, it was found that $B$. sphaericus exhibit $60 \pm 1 \%$ mortality rate compared to the other investigations. Reduced level lethality occurred when treated cell concentration of $5 \mathrm{ml} / \mathrm{l}$ of $B$. sphaericus was used to control Culex pipiens and $C$. quinquefasciatus mosquito larvae and in some areas it is also used to control Anopheles spp. (Surendran and John Vennison 2011). A dosage of $1 \mathrm{~g} / \mathrm{m}^{2}$ was effective to achieve $100 \%$ mortality rate for $C$. quinquefascl. Slate instar larvae in a sewage habitat, with a resi ${ }^{-}$'al effect 1 up to 7 days (Lingenfelser et al. 2010). Murug $n$. (2002) studied the effect of neem seed kernel e. tract with bacterial toxins (B. sphaericus) on the toxicity against filarial vector, Culex quinquefasciatus. $B$. ringiensis toxins break down the larval midgut epithelit n. Kovendan et al. (2011) reported the B. thuringiensis gainst the first- to fourth-instar larvae of values $\mathrm{LC}_{50}=9.332,9.832, \quad 10.212$, and $10.622 \%$ and $\mathrm{LC}_{90}=15.225,15.508,15.887$, and $15.986 \%$ values of Culex quinquefasciatus, respectively. $\mathrm{LC}_{50}$ values of I-IV instars and pupae were 155.29, 198.32, 271.12, 377.44, and $448.41 \mathrm{ppm}$, respectively. Mahesh Kumar et al. (2012) have reported that the $\mathrm{LC}_{90}$ value of $\mathrm{I}$ instar was $687.14 \mathrm{ppm}$, II instar was $913.10 \mathrm{ppm}$, III instar was $1,011.89 \mathrm{ppm}$, IV instar was $1,058.85 \mathrm{ppm}$, and pupa was 1,141.65 ppm of Culex quinquefasciatus, respectively. In the present results, the $\mathrm{LC}_{50}$ and $\mathrm{LC}_{90}$ values third instar larvae and pupae were 4.374-7.406 $\mu \mathrm{l} / \mathrm{ml}$ and $4.928-9.865 \mu \mathrm{l} / \mathrm{ml}$, respectively.

The isolation of $B$. subtilis showing mosquito pupicidal activity assumes greater importance as they can be preserved as spores for long periods. As B. subtilis are a nonpathogenic species, normally found in soil, exhibiting a wide range of physiological and nutritional requirements (Blackwood et al. 2004), they can be cultured easily and used for mosquito control safely. B. subtilis is a ubiquitous bacterium commonly recovered from water, soil, air, and decomposing plant residue. The bacterium produces an endospore that allows it to endure extreme conditions of heat and desiccation in the environment. The culture supernatant of a strain of $B$. subtilis subsp. subtilis isolated from mangrove forests was found to kill larval and pupal stages of mosquitoes through their secondary metabolite 
surfactin (Geetha and Manonmani 2008; Geetha et al. 2010). Previously, Ohba et al. (2000) reported that a $B$. thuringiensis isolate was recovered from brackish sediment in mangroves of the island of Iriomote-jima. It is clear from the present results that $B$. thuringiensis is a rather common member of the microflora in mangrove environments of this island. The organism occurred in the sediments at a frequency of $1.3 \%$ among the $B$. cereus $/ B$. thuringiensis group. This value is comparable with that $(0.9 \%)$ obtained in natural soils of this island (Ohba et al. 2000). Gupta and Vyas (1989) reported a strain of B. subtilis capable of causing mortality of larvae of Anopheles culicifacies, the primary vector of malaria in India. Recently, Das and Mukherjee (2006), Geetha et al. (2007) and Geetha and Manonmani (2008) have reported mosquito larvicidal and pupicidal activities of cyclic lipopeptides (CLPs) secreted by B. subtilis strains. B. cereus also a gram positive, spore forming rod shaped bacteria used for biological control agent widely available in soil environment. B. cereus is a natural facultative mosquito pathogen (Krattiger 1997; Cooping and Menn 2001; Wirth et al. 2004; Teng et al. 2005). B. cereus strains are able to colonize in the guts of the mosquito larvae (Plearnpis et al. 2001). Insecticidal activity of spores of $B$. cereus against $A$. aegypti has been determined by Tyrell et al. (1981). Significant larval reducti $\eta$ was observed using B. cereus as a facultative pathogen for $A$ subpictus Grassi larvae in the natural environmen (Chatterjee et al. 2010). Among the four strains such as $D$ eus, B. subtilis, B. thuringiensis and B. sphaericus solatea mangroves of Vellar estuary, three strain (c ubtilis, $B$. thuringiensis and B. sphaericus) have p tential squitocidal activity. Hence, these mangro e inhabiting bacteria can be used for further research.

Acknowledgments We thank the anities of Annamalai University for providing the necessary $\mathrm{fac}_{\mathrm{m}}$, and the first author thanks to the INCOIS-SATC Proje (G4/515/2008), Ministry of Earth Sciences (Governme it of dia) an / second author thanks to the DST-PURSE Programme, or Science and Technology (Government of Ind a) for ncial support during the period of study. We also th\% the anony, hous referees for the valuable comments, which gratly roved our manuscript.

\section{Ref.. ces}

Abb WS (1925) A method of computing the effectiveness of an in Ácide. J Econ Entomol 18:265-267

Achs J, Malaney P (2002) The economic and social burden of malaria. Nature 15:680-685

Ali A, Nayar JK, Xue RD (1995) Comparative toxicity of selected larvicides and insect growth regulators to a Florida laboratory, population of Aedes albopictus. J Am Mosq Control Assoc 11(1):72-76

Armengol G, Hernandez J, Velez JG, Orduz S (2006) Long-lasting effects of a Bacillus thuringiensis serovar israelensis experimental tablet formulation for Aedes aegypti (Diptera: Culicidae) control. J Econ Entomol 99:1590-1595

Aronson AI, Beckman W, Dunn P (1986) Bacillus thuringiensis and related insect pathogens. Microbiol Rev 50:1-24

Balaraman K (1995) Mosquito control potential of Bacillus thuringiensis subsp. israelensis and Bacillus sphaericus. ICMR Bull 25:45-51

Beatty ME, Letson W, Edgil DM (2007) Estimating the total world population at risk for locally acquired dergue infection. In: Proceedings of 56th annual meeting of A. is .n so iety of tropical medicine and hygiene, Philadelphìa, Tenrsylvania, USA, pp 4-8

Blackwood KS, Turenne CY, Harmse Kabc i AM (2004) Reassessment of sequence-base targe for Identification of Bacillus species. J Clin Micr oiol 42:1620 1630

Chandra G, Bhattacharjee I, Chat rjee SN (2008) Mosquito control by larvivorous fish. Indi $n \mathrm{~J} / \mathrm{Res}$ 27:13-27

Chatterjee S, Subhra Ghosn Das (2010) Virulence of Bacillus cereus as natural facutati athogen of Anopheles subpictus Grassi (Diptera: cidae) las ae in submerged rice-fields and shallow ponds. Afr itechnol 9(41):6983-6987

Cooping LG, M JJ (200 s siopesticides: a review of their action, applicati ns a efficacy. Pest Manag Sci 56:651-676

Darriet F, Ho ro An isolate of Bacillus circulans toxic to mosquito vae. J Am Mosq Control Assoc 18:65-67

Das PI A malraj $\mathrm{L} J$ (1997) Biological control of malarial vectors. Ind an 106:174-197

Das K, Makherjee AK (2006) Assessment of mosquito larvicidal poten $v$ of cyclic lipopeptides produced by Bacillus subtilis strains. Acta Trop 97:168-173

NG, Goswami D, Rabha B (2007) Preliminary evaluation of mosquito larvicidal efficacy of plant extracts. J Vector Borne Dis 44:145-148

de Barjac H, Sebald M, Charles JF, Cheong WH, Lee HL (1990) Clostridium bifermentans serovar Malaysia, a new anaerobic bacterium pathogen to mosquito and blackfly larvae. CR Acad Sci III 310:383-387

Federici BA, Park HW, Sakano Y (2006) Insecticidal protein crystals of Bacillus thuringiensis. In: Shively JM (ed) Microbiology monographs series, inclusions in prokaryotes, vol 1. Springer, Berlin, pp 195-236

Finney DJ (1971) Probit analysis. Cambridge University Press, Cambridge

Geetha I, Manonmani AM (2008) Mosquito pupicidal toxin production by Bacillus subtilis subsp. subtilis. Biol Control 44(2):242-247

Geetha I, Prabakaran G, Paily KP, Manonmani AM, Balaraman K (2007) Characterisation of three mosquitocidal Bacillus strains isolated from mangrove forest. Biol Control 42:34-40

Geetha I, Manonmani AM, Paily KP (2010) Identification and characterization of a mosquito pupicidal metabolite of a Bacillus subtilis subsp. subtilis strain. Appl Microbiol Biotechnol 86(6): 1737-1744

Georghiou GP, Wirth MC (1997) Influence of exposure to single versus multiple toxins of Bacillus thuringiensis subsp. israelensis on development of resistance in the mosquito Culex quinquefasciatus (Diptera: Culicidae). Appl Environ Microbiol 63:1095-1101

Gupta DK, Vyas M (1989) Efficacy of Bacillus subtilis against mosquito larvae Anopheles culicifacies. Zeitschrift fuer Angewandte Zoologie 76:85-91

Khyami-Horani H, Katbeh-Bader A, Mohsen ZH (1999) Isolation of endospore forming bacilli toxic to Culiseta longiareolata (Diptera: Culicidae) in Jordan. Lett Appl Microbiol 128:57-60

Kovendan K, Murugan K, Vincent S, Kamalakannan S (2011) Larvicidal efficacy of Jatropha curcas and bacterial insecticide, 
Bacillus thuringiensis, against lymphatic filarial vector, Culex quinquefasciatus Say. (Diptera: Culicidae). Parasitol Res 109:1251-1257

Kovendan K, Murugan M, Vincent S, Barnard DR (2012) Studies on larvicidal and pupicidal activity of Leucas aspera Willd. (Lamiaceae) and bacterial insecticide, Bacillus sphaericus, against malarial vector, Anopheles stephensi Liston. (Diptera: Culicidae). Parasitol Res 110:195-203

Krattiger F (1997) Insect resistant crops: a case study of Bacillus thuringiensis (BT) and its transfer to developing countries. ISAAA Briefs 2:42

Kumar A, Valecha N, Jain T, Dash AP (2007) Burden of malaria in India: retrospective and prospective view. Am J Trop Med Hyg 77:69-78

Lee YW, Zairi J (2005) Laboratory evaluation of Bacillus thuringiensis $\mathrm{H}-14$ against Aedes aegypti. Trop Biomed 22:5-10

Lingenfelser A, Rydzanicz K, Kaiser A (2010) Mosquito fauna and perspectives for integrated control of urban vector-mosquito populations in Southern Benin (West Africa). Ann Agric Environ Med 17(1):49-57

Maeda M, Mizuki E, Hara M, Tanaka R, Akao T, Yamashita S, Ohba M (2001) Isolation of Bacillus thuringiensis from intertidal brackish sediments in mangroves. Microbiol Res 156:195-198

Mahesh Kumar P, Murugan K, Kovendan K, Subramaniam J, Amaresan D (2012) Mosquito larvicidal and pupicidal efficacy of Solanum xanthocarpum (Family: Solanaceae) leaf extract and bacterial insecticide, Bacillus thuringiensis, against Culex quinquefasciatus Say (Diptera: Culicidae). Parasitol Res. doi: 10.1007/s00436-011-2797-2

Medeiros FP, Santos MA, Regis L, Rios EM, Rolim Neto PJ (2005) Development of a Bacillus sphaericus tablet formulation and is evaluation as a larvicide in the biological control of $\mathrm{Cu}$. quinquefasciatus. Mem Inst Oswaldo Cruz 100:431-434

Murugan K, Thangamathi P, Jeyabalan D (2002) Interactiv effect of botanical and Bacillus thuringiensis subsp. israelensis quinquefasciatus Say. J Sci Ind Res 61:1068-10/6

Nielsen-Leroux C, Charles JF, Thiery I, Geor St GP (1,95) Resistance in a laboratory population of Cul $x$ qu . efasciatus (Diptera: Culicidae) to Bacillus sphaeric is Dmary tox is due to a change in the receptor on midgut bru 1-border membranes. Eur J Biochem 228:206-210

Ohba M, Wasano N, Mizuki E (2000) Bc. thingiensis soil populations naturally occurring Ryukyus, a subtropic region of Japan. Microbiol Res 155:17-

Pandey V, Agrawal V, Raghavendra K, Dash AP (2007) Strong larvicidal activity of $\mathrm{hn}$ specic $\mathrm{y}$ of Spilanthes (Akarkara) against malaria (An ele acies, species C) vector (Culex quinquefasciatus Say). Parasitol Res $2: 171-1 \%$

Park HW, Fede ci (2009) Genetic engineering of bacteria to improve efficacy of the insecticidal proteins of Bacillus specie. In: Stock $\mathrm{SP}$ (ed) Insect pathogens: molecular approach and ni es. 'TABI International, Cambridge, pp 275-305

Park HW, Bh hi D/ , Federici BA (2010) Properties and applied use mos, ,ocidal bacterium, Bacillus sphaericus. J Asia Pac En 1301 13:159-168

Plea is L, Haruyuki A, Sakol P (2001) Isolation of bacterial strains co izable in mosquito larval guts as novel host cells for mosquito control. J Biosci Bioeng 92(4):342-345

Poopathi S, Tyagi BK (2006) The challenge of mosquito control strategies; from primordial to molecular approaches. Biotechnol Mol Biol Rev 1(2):51-65

Poopathi S, Mani TR, Rao DR, Baskaran G, Kabilan L (1999) Crossresistance to Bacillus sphaericus strains in Culex quinquefasciatus resistant to B. sphaericus 1593M. Southeast Asian J Trop Med Publ Health 30:477-481
Rao DR, Mani TR, Rajendran R (1995) Development of a high level of resistance to Bacillus sphaericus in a field population of Culex quinquefasciatus from Kochi, India. J Am Mosq Control Assoc 11:1-5

Rodriguez MM, Bisset J, de Fernandez DM, Lauzan L, Soca A (2001) Detection of insecticide resistance in A. aegypti (Diptera: Culicidae) from Cuba and Veninzula. J Med Entomol 38:623-628

Sharma SK, Upadhyay AK, Haque MA, Tyagi PK, Mghavendra K, Dash AP (2010) Wash-resistance and fid evaluation of alphacypermethrin treated long-lasting inso is ane (Interceptor) against malaria vectors Anopheles ifocies and Anopheles fluviatilis in a tribal area $\circ$ Orissa, Ina. . Acta Trop 116(1):24-30

Shida O, Takagi H, Kadowaki K, Nno Koragata K (1996) Differentiation of species in he Bacillus, evis group and the Bacillus aneurinolyticus gr $\mathrm{p}$ based on the electrophoretic whole-cell protein patter An ie Var Leeuwenhoek 70:31-39

Silva-Filha MH, Regis L, Ison-_uxoux C (1995) Low-level resistance to Bacillas sphae in a field-treated population of Culex quinquefo ${ }^{t}$ us (Dipt, a: Culicidae). J Econ Entomol 88:525-530

Sneath PHA (190 Endospo, lorming Gram positive rods and cocci. In: Snea n Pi A, Mair N, Sharpe M, Holt J (eds) Bergey's manuar c bacteriology, vol II. Williams Wilkins, Baltimore, ${ }_{1}$ 104-1207

Souris "M, Sch te C, Casartelli N (2007) Characterization of ree no. hikungunya virus. PLoS Pathog 3:89

Su T, Mra MS (2004) Documentation of high-level Bacillus sphae izus 2362 resistance in field populations of Culex quinquefasciatus breeding in polluted water in Thailand. J Am Mosq Control Assoc 20:405-411

Su endran A, Vennison SJ (2011) Occurrence and distribution of mosquitocidal Bacillus sphaericus in soil. Acad J Entomol 4(1): 17-22

Teng HJ, Lu LC, Wu YL (2005) Evaluation of various control agents against mosquito larvae in rice paddies in Taiwan. $\mathrm{J}$ Vector Ecol 30:126-132

Tyrell DJ, Lee A, Bulla JR (1981) Characterization of spore coat proteins of Bacillus thuringiensis and Bacillus cereus. Comp Biochem Physiol Part B: Biochem Mol Biol 70(3):535-539

Wirth MC, Georghiou GP, Federici BA (1997) CytA enables CryIV endotoxins of Bacillus thuringiensis to overcome high levels of CryIV resistance in the mosquito, Culex quinquefasciatus. Proc Natl Acad Sci USA 94:10536-10540

Wirth MC, Delecluse A, Walton WE (2004) Laboratory selection for resistance to Bacillus thuringiensis subsp. Jegathesan or a component toxin, Cry 11B, in Culex quinquefasciatus (Diptera: Culicidae). J Med Entomol 41(3):435-441

Wirth MC, Zaritsky A, Ben-Dov E, Khasdan R, Boussiba S, Walton S (2007) Cross resistance spectra of Culex quinquefasciatus resistant to mosquitocidal toxins of Bacillus thuringiensis towards recombinant Escherichia coli expressing genes from B. thuringiensis spp. Israelensis. Environ Microbiol 9:13931401

World Health Organization (1992) Vector resistance to pesticides. Fifth report of the WHO expert committee on vector biology and control. Technical Report Series No. 818. Geneva, Switzerland, WHO

World Health Organization (2009) Mosquito wars. Bull World Health Organ 87:167-168

Yuan Z, Zhang YM, Cali Q, Liu EY (2000) High-level field resistance to Bacillus sphaericus C3-41 in Culex quinquefasciatus from southern China. Biocontrol Sci Technol 10:41-49

Zhang WJ, Jiang FB, Ou JF (2011) Global pesticide consumption and pollution: with China as a focus. Proc Int Acad Ecol Environ Sci 1(2):125-144 